\title{
Authors
}

Chekfoung Tan, School of Computing and Engineering, University of West London, Chekfoung.Tan@uwl.ac.uk, St Mary’s Road, Ealing, London W5 5RF, UK.

\section{Biographical Statement}

Dr Chekfoung Tan is a Senior Lecturer in Applied Project Management working at the University of West London, UK. She is a practice-oriented academic with a decade of academic and industrial experience in managing IT projects. She has a PhD in Informatics from Henley Business School, University of Reading, UK. Her research interests include pedagogical innovation in project management education and the socio-economic impact of digitalisation. She has published in project management and information systems journals and conferences. Her industrial experiences spans across public, private and non-profit sectors. The IT projects she managed or delivered include data-driven knowledge management solution for a global non-profit organisation, food \& beverage system for a managed pub company, application rationalisation project for a local council, and global IT service desk implementation for a multinational manufacturing company.

Isabel Huet, School of Education, University of Hertfordshire, i.huet@ @erts.ac.uk, Hatfield, Hertfordshire AL10 9AB, UK.

\section{Biographical Statement}

Dr Isabel Huet is a Reader in Education working at the University of Hertfordshire, UK. She has nineteen years of teaching and research experience in higher education, including working at different European Universities. She has a vast experience of supervising doctoral students to completion and has participated and led numerous international projects. Her research has been very focused on adult and professional learning. She has been investigating how staff and students learn and teach in Higher 
Education; how institutions, departments and individual staff are working towards improving the quality of teaching, learning and supervision in Higher Education; and on evaluating the impact of professional development of staff in Higher Education. 


\title{
The Design of an Active Learning Strategy to Promote Collaborative and Research-based Learning in Project Management Education
}

\begin{abstract}
Project management $(\mathrm{PM})$ is one of the most popular professions worldwide. Therefore, project management education (PME) has peaked due to its demand in industry. However, research shows that PME focuses too much on PM methodologies. Little has been done in training students in the critical thinking, research, and collaboration skills required by industry. Hence, this paper presents the design of an active learning intervention for PME, which aims at engaging students to learn collaboratively in a research-based learning environment. Following an action research methodology, the authors present the different stages of the study, which took place in a UK university with a group of PM postgraduate students with different levels of work experiences and backgrounds. The pedagogic intervention was evaluated in three stages: 1) non-participant observation, 2) informal feedback, and 3) evaluation survey. Descriptive analysis was adopted for analysing the data collected in stage one. Data collected in stage two and three was analysed by thematic analysis. This research contributes to informing the future design of PME that emphasises on developing students' critical thinking, research and collaboration skills. These skills are crucial for any project management professional and highly sought by industry.
\end{abstract}

Keywords: Active and collaborative learning; research-informed teaching and learning; project management education. 


\section{Introduction}

Higher Education around the world faces a challenging time, in particular with regard to the training of skilled professionals who need to be able to cope with a fast moving, ever-changing environment. Institutions and academics have the mission to educate the new generation of learners and equip them with the knowledge and skills that will allow them to have the capacity to learn and develop, to move and change society, and to become life-long learners. This challenge is not new; several authors have been discussing since the 1980s the importance of transferable and employability skills being part of the curriculum (Brennan and McGeevor, 1987; Poole and Zahn, 1993; Assiter, 1995). More recently, universities and employers have been discussing and revisiting graduate attributes and how these can be developed during programmes of study. Research has been conducted to investigate more innovative teaching and learning approaches to develop the graduate attributes that are needed to fit the current market needs (Osmani, Hindi and Weerakkody, 2018).

The project management profession requires individuals with hard and soft skills (Alam et al., 2010). The hard skills include management surrounding cost, time, scope, quality, change, and risk management (Sumner and Powell, 2013), whereas the soft skills include communication, negotiation, resolving conflicts and team building (Ravindranath, 2016). Project management is an essential curriculum in business education (Ives et al., 2002), and its delivery should mirror the needs of future employers, in particular in terms of the research and critical thinking skills, and collaborative work. The ability of students to work as part of a group organisation, investigate new solutions to problems, follow instructions, but be critical about decisions are essential competencies to consider in project management education. However, most of the existing project management education in general focuses too much on the project management methodologies (Ramazani and Jergeas, 2015) such as the waterfall model like PRINCE2 - 
PRojects IN Controlled Environments (Axelos, 2017) or Agile (Paulk, 2002; Goodpasture, 2010). Ewin et al. (2017) purport that project management educations should cover not only hard and soft skills but also conceptual skills. Here, the conceptual skills refer to the ability of project management graduates to reflect the concepts learned in improving the outcome in practice. In this context, more active and collaborative learning is crucial for engaging students to develop the skills and knowledge required by employers. However, there is a lack of studies in training students' conceptual skills such as the critical thinking, research and collaboration skills required by the industry.

This study intends to fill in this gap by investigating how an active learning intervention engages students to learn collaboratively with each other in a research-based learning environment. This paper is structured as follows: section 2 presents the rationale of the study, sections 3 and 4 discuss the related theories in this paper, section 5 details the methodology used in the study, section 6 illustrates the design of the pedagogic intervention, section 7 describes the evaluation of the intervention and section 8 presents the final considerations and future directions for the teaching and learning of project management.

\section{Project management education: teaching and learning challenges and future directions}

Project management has gained popularity in recent years as there are an increasing number of project-based organisations in the global economy (Wenu and Tan, 2019). The Project Management Institute (2017) suggests that project management profession opportunities will be approaching 87.7 million by 2027 . Project management is unique as each project is unique in its context and has a different level of complexity when managing the interactions between stakeholders and its components (Khodeir, 2018). Therefore, project management education 
programmes are mushrooming, as there is an interest in how to better manage projects in a complex environment (Córdoba and Piki, 2012), such as managing large scale IT projects (Guidry and Totaro, 2013). In the modern era of digitalisation, project management has become an increasingly important element not only in project management education but also in information systems and robotic courses (Guidry and Totaro, 2013; Zadok and Voloch, 2018).

A project environment is seen as a social learning workplace as it includes the project and its relevant stakeholders (Sense, 2011). Social learning happens among the project team members on the job when exchanging knowledge. On the other hand, project management is also an inquiry-based or research-based practice (Lalonde, Bourgault and Findeli, 2012) where the project stakeholders are also the researchers, who should continuously question their actions and decisions in a project environment. However, with a strong emphasis on project management methodologies, the provision of traditional project management education does not prepare graduates sufficiently for dealing with the project complexities in the real world or meeting the industry requirements (Winter et al., 2006; Khodeir, 2018), nor does it equip them with the soft skills required (e.g. communication, negotiation, and teamwork) (GonzálezMarcos et al., 2016; Ewin et al., 2017). Khodeir (2018) claims that some of the challenges of project management education include inefficient teaching and learning methods, a lack of interactions between teachers and students, the use of inefficient tools, irrelevant content or a lack of rigour in the content regarding knowledge, skills and attitude, traditional theory-based classroom learning, and students' premade assumptions and perceptions about project work.

Hence, apart from hard or technical skills, the delivery of project management education should also focus on developing research, soft and conceptual skills. Future graduates should be able to find solutions to new problems, be able to provide in-depth information, detailed analysis 
and suitable advice to their clients, and demonstrate interpersonal and leadership skills in engaging with real-life projects or situations (Ramazani and Jergeas, 2015; Ewin et al., 2017). With this purpose in mind, course teams need to focus on the pedagogical design of the teaching delivery. Project management education should incorporate theoretical and practical elements (Bergman and Gunnarson, 2014; Khodeir, 2018), which will better contribute to the achievement of the proposed learning outcomes for the course. Traditionally, the theoretical elements are delivered through lectures and reading of selected academic papers. Moreover, the practical part consists of a design or setting where students can apply the theories they learn to real-life situations. Therefore, teachers should design relevant learning situations or activities where students can reflect and employ the knowledge gained. For instance, conflict management is an essential skill for students to learn in project management. Teachers can first introduce the conflict management theory to students, which can be followed by role-playing activities that involve the students in resolving conflict. Teachers should provide instant feedback and a debriefing session to students after a practical activity (Khodeir, 2018). Moreover, the theoretical element of project management education should cover the general knowledge areas of project management, and the practical element should focus on the practice-related or industry-specific setting (Córdoba and Piki, 2012; González-Marcos et al., 2016).

\section{Active and collaborative learning}

Active learning is defined as "the result of a deliberate and conscious attempt on the part of a teacher to cause students to participate overtly in a lesson" (Pratton and Hales, 1986, p. 211). It refers to practices that engage students in the learning process and in higher-order thinking tasks, such as analysis, synthesis, and evaluation (Bonwell and Eison, 1991). Active learning activities imply the active participation of students in doing things and thinking about what 
they are doing (Bonwell and Eison, 1991), where students do more than passively listen to a lecture. Active learning is therefore grounded on experiential and generative learning theories (Kolb, 1984; Wittrock, 1992; Hanke, 2012) since learning takes place when students are actively engaged in doing something that involves the "active integration of new ideas with the learner's existing schemata" (Hanke, 2012, p. 1358). It is worth mentioning that students can have a positive or negative reaction towards active learning strategies (Svinicki and Dixon, 1987), since some students prefer to be receivers (observers or listeners), while others will prefer to be active participants (Bonwell and Eison, 1991). Either way, there will always be the need to find a good balance of activities in order to address the learning preferences of all of the students. Most important is to acknowledge that various studies have concluded that learning that involves talking and listening, writing, reading and reflecting or flipped learning can increase student success rates over more traditional teaching-delivery formats (Knight and Wood, 2005; Yoder and Hochevar, 2005; McNally et al., 2017).

One of the most beneficial methods of active learning is collaborative learning, which occurs when students work together in small groups towards a common goal, creating meaning, exploring a topic or improving skills (Prince, 2004). Collaborative learning is rooted in social learning theories where behaviours are produced and maintained by interactions between a person and the environment or within a community (Bandura and Walters, 1977). According to $\mathrm{Xu}$ and Wang (2014), social learning theory has been applied in many fields such as medicine and pedagogy. Learning is perceived as a social process in the lens of social learning where students interact with their peers as well as the situation, such as a learning environment (Yu et al., 2010). The benefits of social learning theory in the learning environment include (adapted from Kytle, 1978; Gherardi, Nicolini and Odella, 1998; Yu et al., 2010; Kim, 2012): 1) understanding students' behaviour within a classroom setting, 2) explaining students' 
behavioural development through the process of participation and interaction, 3) encouraging a collective and participative learning environment that eventually leads to knowledge contribution in the classroom teaching, and 4) encouraging students to learn through practice from observing their peers and acquiring the relevant information. Similar to social learning, collaborative learning is an approach that involves groups of learners working together and sharing their knowledge in problem solving, task completion and product creation (Mitnik et al., 2009; Laal and Laal, 2012). This approach encourages learners to discover and exploit their skills by asking one another for information, and evaluating their and others' ideas and work (Chiu, 2000, 2008).

The landscape of higher education has shifted in recent years from the notion where learners are seen as "a sponge" to one where they are seen as "the active constructors of meaning" (Wilson and Peterson, 2006). Hence, learning is a social process that involves active engagement from the learners. This shift to a more student-centred learning approach has created a new way of teaching that combines the core of "teaching-centred" and "learningcentred" approach (Finkelstein et al., 2016). In this context, learners need to have a more active role in learning while teachers are the mediators, supervisors or tutors; supporting and guiding students in their learning journey, challenging them to construct and apply the knowledge that is new and meaningful to them, and providing relevant feedback that can be used to improve their learning (Huet, 2017; Carless and Boud, 2018). Pedagogy has become a vital aspect of ensuring efficient teaching and learning (Šimúth and Hvorecký, 2016).

\section{Research-informed teaching}

Research-informed teaching establishes the link between teaching and research as "the connection between research in the discipline or interdisciplinary subjects and student 
learning in and through those disciplines" (Zetter, 2002). Various terms have been produced in describing the research-informed teaching concept such as the teaching-research relationship, the teaching-research nexus, inquiry-based learning, and research-based teaching (Gresty et al., 2013). In other words, research-informed teaching can be defined as the engagement of students in learning through research and/or inquiry. The focus is on how teachers plan and deliver teaching activities that expose students to investigating disciplinary problems, making judgments on the basis of sound evidence, making decisions on a rational basis, and understanding what they are doing and why it is vital (Brew, 2007). Researchinformed teaching is part of a more holistic concept that is referred to as research-based education (Huet, 2017). This approach to education is shaped by the Humboldt ideal of a university where research and teaching take place side-by-side, and by Newman's ideal of useful and liberal knowledge where students are guided/supported to be a community of thinkers, who are able to "think and to reason, to compare, to discriminate and to analyse" (Newman, 2010, p. 256).

Healey and Jenkins (2009), drawing on the work of Griffiths (2004) and Healey (2005), present four main ways of engaging students with research and inquiry. The framework consists of four quadrants: research-led, research-oriented, research-based and research-tutored. According to Huet (2017), this framework is adjusted into two main approaches: researchbased teaching and learning and research-led teaching and learning. Research-based teaching and learning occur when teachers plan, deliver and assess students' work through their involvement in research or inquiry-based activities. Here students are more active learners, constructing knowledge in a research environment with the guidance of teachers. The curriculum is therefore structured around these activities. Students learn through authentic 
enquiry by undertaking learning activities, which reflect the processes of research and are assessed through activities that mirror research and inquiry processes.

Research-led teaching and learning occur when teachers use their expertise as active researchers or use the research of others to inform their teaching, whilst their own research ideas and approaches are stimulated and sharpened through interactions with the students. The curriculum is structured around subject content and is based on the teachers' research interests. This occurs by exposing students to research ideas and approaches, stimulating debate and provoking questions. Students can be either passive, by listening to the teacher, or active, through participating in the discussions. Some research skills can also be developed, such as the ability to be involved in theoretical reflections or discussions, and also the ability to make decisions and to justify options or perspectives.

These two approaches to teaching and learning contribute to the development of higher-level cognitive skills and increase students' responsibility for their own learning, benefiting both teachers and students (Gresty et al., 2013). The students are encouraged to generate new ideas and to provide new insights during the process, which contributes to their personal development. Students start constructing knowledge that is new to them and develop skills that will bring them from the level of novice to expert learners (Dreyfus, 2004, Huet, 2017). As for the teachers, research-informed teaching ensures the currency of the teaching content and hence enhances the academic credibility and students' motivation. More importantly, researchinformed teaching strengthens the relationship between students and teachers.

Research-informed teaching is as a problem solving approach from the learners' or students' perspective (Pedaste and Sarapuu, 2006). It provides an environment for learners to discover new knowledge through research, and it requires active participation from the learners (De 
Jong and Van Joolingen, 1998). In addition, this approach enables learners to self-direct the learning process, - to investigate the context of study or to resolve the problems provided (Wilhelm and Beishuizen, 2003). There are five phases in facilitating this approach (see Figure 1) (Pedaste et al., 2015): orientation, conceptualisation, investigation, conclusion, and discussion and reflection.

Orientation refers to the process of acknowledging the potential issues through the given problem statement. Conceptualisation relates to the method of making a theoretical or empirical hypothesis. The investigation is the process where learners are exploring possible solutions to the problems by collecting and analysing the relevant data. The conclusion is the process where students are asked to compare their findings with the theoretical hypotheses made. The discussion and reflection refer to the process where learners are reflecting on the whole inquiry or problem-solving cycle, and they communicate with each other or through some reflective activities conducted by the teachers.

\section{Methodology}

Since one of the researchers was investigating her practice with the ultimate aim of changing the student's learning experience in PM education, the chosen methodology for this study was action research (Mansour, 2015; Shelley, 2015). In line with Norton's (2009) work, the authors designed a pedagogic intervention project with the purpose of systematically investigating the teaching and learning of a management module with the dual aim of modifying practice and contributing to the theoretical knowledge in the area of management education. The design of the study follows the methodological steps of action research with four distinctive phases: identification of the problem (problem statement), design and implementation of the pedagogic 
intervention, evaluation of the impact and reflection. Each phase is explored, in detail, in the next section of the paper.

\section{Pedagogic intervention}

The authors conducted the pedagogic intervention in one of the modules, the Team Dynamics and Leadership module, of a postgraduate project management course delivered by a UK University. The core modules and curriculum of this course are developed based on the core competencies required by the industry. The course recruits students with various academic levels and industry backgrounds.

\subsection{Problem statement}

Based on a one-month observation of students' interactions in class, the first author found that students who were experienced professionals (current or former) and possessed industrial experience or expertise tended to engage in the classroom by referring to anecdotal evidence or using common sense. This group of students struggled to apply theories in discovering or innovating project management practices. On the other hand, students who did not have prior industrial or work experience were keen to engage with theories. However, both groups of students struggled to engage in the classroom by visualising how the theories could be related to real-life project management practice. Students were generally lacking in research skills, which caused different levels of engagement with the teaching delivery in this course. Research skills are vital for students in becoming successful project management professionals upon their graduation. Moreover, the authors felt that active and collaborative learning should be incorporated into the teaching delivery to enable students to grasp the theoretical concepts and how to apply them in industry, regardless of their prior industrial experience. 


\subsection{Design and implementation of the pedagogic intervention}

Negotiation and conflict management is essential in project management, as conflicts could happen at any stage of a project (Anthopoulos and Xristianopoulou, 2012). Hence, the authors selected an activity related to conflict management in the Team Dynamics and Leadership module, which also required negotiation skills, to conduct the pedagogic intervention. The students were taught about various negotiation skills and the BATNA (Best Alternative to a Negotiated Agreement) theory proposed by Fisher, Ury and Patton (2011) before the activity on conflict management. The activity aimed to engage students better in the whole lecture delivery and for them to research, reflect and apply the negotiation theories in managing conflict. BATNA is commonly applied in the real world. It helps the negotiators to understand the alternatives before accepting an agreement. BATNA is particularly useful when negotiating a potential solution when conflict happens. The learning activity was adapted from "The Prisoner's Dilemma" from Martin (2017), and it was called "Red vs. Blue" (see Figure 2). The authors carried out this activity with two cohorts (2018 and 2019) of students (see Table 1).

The implementation of this pedagogic intervention remained the same for both cohorts of students. The teacher (the first author) randomly separated the students into two groups before the activity and took the students to two different rooms. The students were not informed about the activity beforehand. They were expecting that the lecture for the week would be about conflict management. The students were told not to communicate with each other. An instruction pack was handed out to both teams after they had settled in the two different rooms. The instruction pack consisted of the guidelines for the activity (see Figure 3), a score table (see Figure 4), and a score sheet (see Figure 5). 
The students were given five minutes to read the guidelines. The teacher then started the clock and the students were asked to start the activity. The teacher made it clear to the students that she was serving as the activity facilitator or observer and that she would not provide any consultation. The students had the option to send a representative for the negotiation rounds (after round 4 and round 8). The negotiation was about playing "Red" or "Blue". The overall marks were affected by the score table as in Figure 4. The teacher observed the students' behaviour during the activity (see Section 7.1). At the end of the activity, the teacher gave the students a 10 minute break, and they were told not to communicate with each other about the possible results. This break was a cooling down period as a few team members were very emotional about the trust issue they had encountered in the activity. Figures 6 and 7 show the activity results for both cohorts of students. Ultimately, the objective of this intervention was to ensure the students researched and applied BATNA in the activity.

\section{Evaluation of the pedagogic intervention}

The evaluation was done in three stages to affirm the validity of this pedagogic intervention, as it was socially constructed (Mishler, 1990; Kvale, 1995). Firstly, the non-participant observation was conducted by the teacher (the first author) during the pedagogic intervention by following the five stages of the learning process, as suggested by Pedaste et al. (2015). Nonparticipant observation is a type of observational method that involves the analysis and interpretation of people's (the students in this paper) behaviour (Morgan, Pullon and McKinlay, 2015; Saunders, Lewis and Thornhill, 2016). Field notes were collected to record the students' learning behaviour and engagement in the class. This research has considered the potential impact of the Hawthorne Effect (French, 1953). Hawthorne Effect refers to the altered behaviour of research participants when being observed. The teacher adapted Paradis and Sutkin (2017)'s principle of developing rapport with the research participants in minimising the 
Hawthorne Effect. In this research, the teacher had established a good relationship with the students, which has also been maintained outside the formal teaching sessions during the tutoring sessions.

Secondly, the teacher collected informal feedback at the end of the lecture, with the aim of gathering students' perceptions of the activity in terms of helping them to grasp the essence of negotiation and conflict management theories and how to employ the theories in an actual situation. For the 2018 cohort, the feedback was provided verbally from the students. For the 2019 group, the authors devised a few open-ended questions (see Appendix 1) to systematically capture the students' feedback. The changes made enabled students to reflect on their learning. For instance, the question regarding what students would do differently when managing a conflict, enabled students to relate the learning to real-life examples. Moreover, by understanding what students liked the most and the least about the activity, the teacher could then improve her teaching practice in the future. For both cohorts, the implemented changes helped to increase students' engagement level during the activity. The teacher asked the students to write down their thoughts on post-it notes (Figure 8) and stick them on the wall; this was followed by an overall discussion. This exercise aimed to help the students to visualise the key learning points.

Lastly, a survey was distributed to the students after the lecture, with the aim of validating the pedagogic intervention in terms of improving students' research and theory application skills (adopted from Sandelowski, 1998). The evaluation survey was designed based on the pedagogic innovation themes, such as novelty, change, and reflection, suggested by Walder (2014). The novelty theme examined whether the way of delivering new knowledge was different compared to the previous lectures and whether it had surprised the students. The change aspect studied whether the activity brought any further changes to the lecture delivery, 
and the reflection perspective enabled the teacher to review whether the intervention had successfully achieved the study propositions. Appendix 2 shows the questions in the evaluation survey delivered in 2018. Based on the survey results, the authors made a few minor changes to the evaluation survey, as in Appendix 3. The changes aimed to capture more perspectives for this study.

In terms of the data analysis, the authors employed qualitative data analysis methods such as descriptive analysis and thematic analysis. The descriptive analysis illustrates various aspects that happen in a phenomenon (Elliott and Timulak, 2005), which refers to the pedagogic intervention in this paper (see results in Section 7.1). Thematic analysis offers a systematic approach to analysing qualitative data by deriving patterns across the datasets (Braun and Clarke, 2006). The authors coded the data in various themes (see results in Section 7.2) following an inductive approach and coded other data following a deductive approach (see results in Section 7.3). The codes and themes were developed and modified through reviewing the data in detail several times. The second author reviewed approximately $30 \%$ of the data set and her coding agreed with the first author $75 \%$ of the time before reconciliation, and $95 \%$ after reconciliation.

The themes contributed to understanding whether the students had found the intervention engaging and whether it had helped them to research a better way of resolving conflicts. The triangulation of the data collected from the non-participant observation, informal feedback and evaluation survey provided an accurate narrative of the phenomenon (Robson and McCartan, 2016). The data collected from three different sources enabled the authors to gain an in-depth understanding of the efficiency of the design of the pedagogic intervention. 


\subsection{Non-participant observation of the intervention}

The teacher conducted the non-participant observation during the intervention. Table 2 summarises the observation made by the teacher during the intervention.

Following Huet (2017), the teacher executed the research-based and research-led teaching and learning principles. From the research-based perspective, students from both cohorts were active learners. They applied the research skills to a certain level when trying to understand the problem domain and devise a negotiation strategy. However, the students in the 2018 cohort showed a higher level of attention to detail compared to the 2019 cohort. The 2018 cohort understood the instructions (e.g. 3 minutes in each round of negotiation), whereas the 2019 cohort were not aware of the time limit until the teacher reminded them. Both groups acknowledged that negotiation skills were vital in resolving the conflict in this activity. The 2019 cohort had a quick reflection on the negotiation theories (e.g., BATNA) in the early stage of the activity, and the 2018 cohort recalled the theory at a later stage of the activity. Still, neither cohort could work out a win-win strategy, which caused a win-lose situation by applying BATNA. However, both cohorts of students appreciated the importance of BATNA and how they could use it better in the real world based on the experience they had had in the activity. From the research-led perspective, the teacher applied her expertise in project management research to inform the teaching of the negotiation theory, BATNA, in addressing the conflict scenario.

\subsection{Informal feedback from participants}

The teacher solicited informal feedback from the students, which lasted for 30 minutes. The informal feedback was in line with active and collaborative learning theories where students engage in a discussion, reflecting on the activity and sharing their knowledge. Table 3 
illustrates the themes that emerged from the feedback. Compared to the 2018 cohort, a structured approach was employed to collect the informal feedback from the 2019 cohort. The authors discovered not only the key themes but also the sub-themes and the number of occurrences from the 2019 cohort. Therefore, the data from 2019 data is richer than that from 2018.

Active learning happened for both cohorts of students, where students learned from doing things (Bonwell and Eison, 1991). For the 2019 cohort, there were various sub-themes derived from the learning gains. This scenario shows that the students not only learned negotiation skills when resolving conflict through the BATNA theory, but they also grasped the essence of applying BATNA in the real world. Based on the informal feedback from the 2019 cohort, collaborative learning took place when the students realised that trust and respect were vital in the project team management. Trust and respect are core elements for surviving critical moments in a project team, according to the students. This finding reflects the same proposition purported by Pinto, Slevin and English (2009), where trust and respect foster positive relationships among project stakeholders. This intervention has demonstrated the essence of active learning and collaborative learning in project management education. A few students from the 2019 cohort did not like the "uncertainty" element in this intervention. Nevertheless, dealing with "uncertainty" is part of risk management, which is also an essential aspect of the project management discipline (Axelos, 2017). In a nutshell, the students from the 2018 and 2019 cohorts learned the key essence of project management, such as negotiation, conflict and team management, in a pragmatic manner. 


\subsection{Evaluation survey}

In general, students from both cohorts found that this activity was engaging. Based on the pedagogic innovation themes such as novelty, change, and reflection discussed by Walder (2014), Table 4 depicts the outcomes collected from the students in the 2018 and 2019 cohorts.

Based on the overall comments, students from both cohorts felt that this pedagogic intervention had helped them to learn BATNA and its application in managing conflict better. Students especially found that this intervention enabled them to appreciate this theory in managing reallife conflict. However, the results from the two cohorts were slightly different in regard to the pedagogic innovation themes. The novelty theme regarding whether the intervention had changed the usual teaching delivery showed an increase in relation to the traditional classroom delivery. However, there was a decrease in percentages in terms of the change and reflection of this intervention when comparing the two cohorts. As part of the research-led approach from the research-informed teaching principle, the teacher believed that the decrease in percentage was due to the team dynamics. Team dynamics are highly related to the team composition theory proposed by Belbin (2012). Belbin suggests that a successful team consists of a wellbalanced mix of thinking, people and action-oriented team roles. Both cohorts of students had done a self-assessment based on Belbin's principles in an earlier session of this module. The 2018 cohort had a better mix of students in terms of their team roles compared to the 2019 cohort. However, the overall module assessment results showed that the 2019 students performed better than the 2018 students (see Figure 9). The assessment included a written assignment and a written exam. Students were required to review the theories and critically apply them in the real world. 
In summary, this intervention showed positive results in terms of student engagement. From the research-based learning perspective, this intervention successfully improved students' research and theory application skills. This intervention simulated a real-life scenario for students who were lacking in industrial experience to learn how to apply theories in practice. Moreover, this intervention enabled students to sharpen their critical thinking skills. This aspect is clearly shown, as students with rich industrial experience appreciated the theories more and how they could help in innovating their practices.

\section{Final considerations and future directions}

Project management education should focus on producing graduates who are rich in research, critical thinking and collaborative skills (Ives et al., 2002). As opposed to traditional classroom delivery, pedagogical innovation plays a significant role in project management education in terms of improving the learning experiences of the students (adapted from Gordon, 2014). The main contribution of this study is the design of a pedagogic intervention that aimed to engage students to learn collaboratively in a research-based learning environment to fulfil the industry needs of project management graduates. Moreover, this research contributes to informing the future design of project management education by demonstrating a teaching strategy that can facilitates the development of students' critical thinking, research and collaboration skills. The teacher (the first author) conducted the pedagogic intervention in the Team Dynamics and Leadership module with students enrolled in 2018 and 2019. The pedagogic intervention was evaluated via non-participant observation, informal feedback and an evaluation survey. The non-participant observation enabled the teacher to understand the students' learning pattern (e.g., how students approached the given problem). The informal feedback engaged students in discussing, reflecting on and sharing the knowledge gained from the intervention, and the evaluation survey validated the applicability of the intervention, and whether it had helped in 
improving the students' research and theory application skills. Overall, the intervention yielded positive results from both cohorts of students, and the results contributed to informing the future directions of project management education.

\subsection{Study limitations}

The main limitation of this study is the lack of textual feedback collected from the students with no work experience. This scenario happened in both cohorts of students. Students who had work experience provided most of the verbal and textual feedback. The number of students with no work experience was comparatively lower than those who had worked in the industry for at least a year. Future studies will focus on redesigning the evaluation instruments such as the method for collecting the informal feedback and the questions posed in the evaluation survey.

\subsection{Future directions for Project Management Education}

The literature suggests that soft skills are essential in project management education, and that project management graduates should be equipped with strong research, critical thinking and collaborative skills. Hence, research-informed teaching, together with active and collaborative learning are essential teaching and learning approaches for designing an effective learning environment for management education. Additionally, this paper recommends three different approaches (non-participant observation, informal feedback and evaluation survey) in evaluating the efficiency of any form of pedagogic intervention. The evaluation data will then help in improving the design and delivery of project management education. 
As opposed to the traditional theory-based classroom learning, this study demonstrated an innovative approach in teaching and learning delivery. Figure 10 depicts the new delivery approach for project management education.

Project management education should reflect the research-informed teaching principles by integrating a balanced mix of lecture-led seminars and seminar-led lectures sessions. Here, the lectures should impart the theory delivery, and the seminars would be the activities that engage students to do things such as role-playing and real case problem solving. The lecture-led seminar is a delivery session of a lecture followed by a seminar. The seminar-led lecture is a delivery session of a seminar which is followed by a lecture. In this way, the delivery will enable students to be active learners by engaging them in the seminar, in particular in researching and applying the theories they have picked up from the lecture (lecture-led seminar), or reflecting on the past theories in the real-life simulated seminar (seminar-led lecture). Through the seminar process, the students can learn from each other, which will help them to contribute to the understanding of theory and its application in the real world, where collaborative learning happens. Also, aligning with Signori et al. (2018), the gamification concept could be introduced in the seminar sessions to increase the students' engagement to learn. For instance, students could play games such as Traffic Jam (WorkRFun, 2020) in learning how to create a high performance project team. 


\section{References}

Alam, M, Gale, A, Brown, M and Khan, A I (2010) 'The importance of human skills in project management professional development', International Journal of Managing Projects in Business, 3(3), pp. 495-516.

Anthopoulos, L G and Xristianopoulou, A (2012) Negotiation Models for Managing Projects. Master of Project Management thesis). Available at: http://mibes.teilar.gr/proceedings/2012/oral/Anthopoulos-Christianopoulou.pdf.

Assiter, A (1995) 'Transferable skills: A response to the sceptics', Transferable Skills in Higher Education. London, Kogan Page.

Axelos (2017) What is PRINCE2? | PRINCE2 | AXELOS, Axelos [Online]. Available at: https://www.axelos.com/best-practice-solutions/prince2/what-is-prince2 ～(Accessed: 1 February 2018).

Bandura, A and Walters, R H (1977) 'Social learning theory'.

Belbin, R M (2012) Team roles at work. Routledge.

Bergman, I and Gunnarson, S (2014) 'Teaching organizational project management at postgraduate level', Procedia-Social and Behavioral Sciences. Elsevier, 119, pp. 446-455.

Bonwell, C and Eison, J (1991) Active Learning: Creating Excitement in the Classroom. 1991 ASHE-ERIC Higher Education Reports., ASHE-ERIC Higher Education Report.

Braun, V and Clarke, V (2006) 'Using thematic analysis in psychology', Qualitative research in psychology. Taylor \& Francis, 3(2), pp. 77-101. 
Brennan, J and McGeevor, P (1987) Employment of Graduates from Ethnic Minorities: A Research Report. Commission for Racial Equality London.

Brew, A (2007) 'Integrating research and teaching: understanding excellence', in Skelton *, A. (ed.) International Perspectives on Teaching Excellence in Higher Education. Routledge.

Carless, D and Boud, D (2018) 'The development of student feedback literacy: enabling uptake of feedback', Assessment \& Evaluation in Higher Education. Routledge, 43(8), pp. 1315-1325.

Chiu, M M (2000) 'Group Problem-Solving Processes: Social Interactions andIndividual Actions', Journal for the theory of social behaviour, 30(1), pp. 26-49.

Chiu, M M (2008) 'Flowing toward correct contributions during group problem solving: A statistical discourse analysis', The Journal of the Learning Sciences, 17(3), pp. 415-463.

Córdoba, J-R and Piki, A (2012) 'Facilitating project management education through groups as systems', International Journal of Project Management. Elsevier, 30(1), pp. 83-93.

Dreyfus, S E (2004) 'The Five-Stage Model of Adult Skill Acquisition', Bulletin of Science, Technology \& Society, 24(3), pp. 177-181.

Elliott, R and Timulak, L (2005) 'Descriptive and interpretive approaches to qualitative research', A handbook of research methods for clinical and health psychology, pp. 147-159.

Ewin, N, Luck, J, Chugh, R and Jarvis, J (2017) 'Rethinking Project Management Education: A Humanistic Approach based on Design Thinking', in Procedia Computer Science, pp. 503510.

Finkelstein, A, Ferris, J, Weston, C and Winer, L (2016) 'Research-Informed Principles for 
(Re)Designing Teaching and Learning Spaces', Journal of Learning Spaces.

Fisher, R, Ury, W and Patton, B (2011) Getting to Yes Negotiating an Agreement without Giving In. USA: Penguin Random House Business Books.

French, J R (1953) 'Experiments in field settings', in Research Methods in the Behavioral Sciences. New York: Rinehart and Winston, pp. 98-135.

Gherardi, S, Nicolini, D and Odella, F (1998) 'Toward a social understanding of how people learn in organizations: The notion of situated curriculum', Management Learning, 29(3), pp. 273-297.

González-Marcos, A, Alba-Elías, F, Navaridas-Nalda, F and Ordieres-Meré, J (2016) ‘Student evaluation of a virtual experience for project management learning: An empirical study for learning improvement', Computers \& Education. Elsevier, 102, pp. 172-187.

Goodpasture, J (2010) Project management the agile way: Making it work in the enterprise. J. Ross Publishing.

Gordon, N (2014) Using Pedagogy and Learning Analytics to Manage Our Students. Available at: https://www.heacademy.ac.uk/system/files/resources/gen-108-o.pdf.

Gresty, K A, Pan, W, Heffernan, T and Edwards-Jones, A (2013) 'Research-informed teaching from a risk perspective', Teaching in Higher Education, 18(5), pp. 570-585.

Griffiths, R (2004) 'Knowledge production and the research-teaching nexus: The case of the built environment disciplines', Studies in Higher education, 29(6), pp. 709-726.

Guidry, B N and Totaro, M W (2013) 'MIS students and the systems analysis and design course 
project: a proposed experiential approach', International journal of innovation and learning. Inderscience Publishers Ltd, 13(2), pp. 121-139.

Hanke, U (2012) 'Generative Teaching: Improvement of Generative Learning', Encyclopedia of the Sciences of Learning. Springer, pp. 1358-1360.

Healey, M (2005) 'Linking research and teaching to benefit student learning', Journal of Geography in Higher Education, 29(2), pp. 183-201.

Healey, M and Jenkins, A (2009) Developing undergraduate research and inquiry. York: Higher Education Academy.

Huet, I (2017) 'Research-based education as a model to change the teaching and learning environment in STEM disciplines', European Journal of Engineering Education. Taylor \& Francis, pp. 1-16.

Ives, B, Valacich, J S, Watson, R T, Zmud, R W, Alavi, M, Baskerville, R, Baroudi, J J, Beath, C, Clark, T and Clemons, E K (2002) 'What every business student needs to know about information systems', Communications of the Association for Information Systems, 9(1), p. 30.

De Jong, T and Van Joolingen, W R (1998) 'Scientific discovery learning with computer simulations of conceptual domains', Review of educational research, 68(2), pp. 179-201.

Khodeir, L M (2018) 'Blended learning methods as an approach to teaching project management to architecture students', Alexandria engineering journal. Elsevier, 57(4), pp. 3899-3905.

Kim, H (2012) 'Understanding Online Knowledge Contribution in Social Learning Perspective', European Conference of Information Systems (ECIS2012). Barcelona, p. 226. 
Knight, J K and Wood, W B (2005) 'Teaching more by lecturing less', Cell biology education. Am Soc Cell Biol, 4(4), pp. 298-310.

Kolb, D A (1984) Experiential learning: experience as the source of learning and development. Prentice-Hall.

Kvale, S (1995) ‘The social construction of validity’, Qualitative inquiry, 1(1), pp. 19-40.

Kytle, J (1978) 'Book Reviews: Social Learning Theory by Albert Bandura. Contemporary Sociology', pp. 84-85.

Laal, Marjan and Laal, Mozhgan (2012) 'Collaborative learning: what is it?', Procedia-Social and Behavioral Sciences, 31, pp. 491-495.

Lalonde, P L, Bourgault, M and Findeli, A (2012) 'An empirical investigation of the project situation: PM practice as an inquiry process', International Journal of Project Management.

Mansour, H F (2015) 'Enhancing first year management students' engagement: An action research project to explore the use of the Essay Feedback Checklist (EFC)', The International Journal of Management Education. Elsevier, 13(3), pp. 218-226.

Martin, N (2017) Prisoner's Dilemma (aka Reds \& Blues), WorkshopBank. Available at: https://workshopbank.com/prisoners-dilemma (Accessed: 1 November 2018).

McNally, B, Chipperfield, J, Dorsett, P, Del Fabbro, L, Frommolt, V, Goetz, S, Lewohl, J, Molineux, M, Pearson, A and Reddan, G (2017) 'Flipped classroom experiences: student preferences and flip strategy in a higher education context', Higher Education. Springer, 73(2), pp. 281-298. 
Mishler, E G (1990) 'Validation in inquiry-guided research: The role of exemplars in narrative studies', Harvard educational review, 60(4), pp. 415-443.

Mitnik, R, Recabarren, M, Nussbaum, M and Soto, A (2009) 'Collaborative robotic instruction: A graph teaching experience', Computers \& Education, 53(2), pp. 330-342.

Morgan, S, Pullon, S and McKinlay, E (2015) 'Observation of interprofessional collaborative practice in primary care teams: an integrative literature review', International Journal of Nursing Studies. Elsevier, 52(7), pp. 1217-1230.

Newman, J H (2010) Discourses on the Scope and Nature of University Education: Addressed to the Catholics of Dublin. Cambridge University Press (Cambridge Library Collection Education).

Norton, L S (2009) Action research in teaching and learning: A practical guide to conducting pedagogical research in universities. Abingdon, UK: Routledge.

Osmani, M, Hindi, N M and Weerakkody, V (2018) 'Developing Employability Skills in Information System Graduates', International Journal of Information and Communication Technology Education, 14(2), pp. 17-29.

Paradis, E and Sutkin, G (2017) 'Beyond a good story: from Hawthorne Effect to reactivity in health professions education research', Medical education. Wiley Online Library, 51(1), pp. $31-39$.

Paulk, M C (2002) 'Agile Methodologies and Process Discipline', Institute for Software Research, pp. 15-18.

Pedaste, M, Mäeots, M, Siiman, L A, De Jong, T, Van Riesen, S A N, Kamp, E T, Manoli, C 
C, Zacharia, Z C and Tsourlidaki, E (2015) 'Phases of inquiry-based learning: Definitions and the inquiry cycle', Educational research review, 14, pp. 47-61.

Pedaste, M and Sarapuu, T (2006) 'Developing an effective support system for inquiry learning in a Web-based environment', Journal of Computer Assisted Learning, 22(1), pp. 47-62.

Pinto, J K, Slevin, D P and English, B (2009) 'Trust in projects: An empirical assessment of owner/contractor relationships', International Journal of Project Management.

Poole, V A and Zahn, D K (1993) 'Define and Teach Employability Skills to Guarantee Student Success', The Clearing House: A Journal of Educational Strategies, Issues and Ideas. Taylor \& Francis Group , 67(1), pp. 55-59.

Pratton, J and Hales, L W (1986) 'The effects of active participation on student learning', The Journal of Educational Research. Taylor \& Francis, 79(4), pp. 210-215.

Prince, M (2004) 'Does active learning work? A review of the research', Journal of engineering education. Wiley Online Library, 93(3), pp. 223-231.

ProjectManagementInstitute (2017) Job Growth and Talent Gap in Project Management 2017, 2017. Available at: https://www.pmi.org/-/media/pmi/documents/public/pdf/learning/jobgrowth-report.pdf?sc_lang_temp=en. (Accessed: 12 August 2019).

Ramazani, J and Jergeas, G (2015) 'Project managers and the journey from good to great: The benefits of investment in project management training and education', International Journal of Project Management.

Ravindranath, S (2016) 'Soft Skills in Project Management: A Review', IUP Journal of Soft Skills. 
Robson, C and McCartan, K (2016) Real World Research, Edition. Blackwell Publishing. Malden.

Sandelowski, M (1998) 'The call to experts in qualitative research', Research in nursing \& health, 21(5), pp. 467-471.

Saunders, M N K, Lewis, P and Thornhill, A (2016) Research Methods For Business Students (Seventh Edition). 7th editio. England: Pearson Education Limited.

Sense, A J (2011) 'The project workplace for organizational learning development', International Journal of Project Management.

Shelley, A W (2015) 'Project management and leadership education facilitated as projects', International Journal of Managing Projects in Business. Emerald Group Publishing Limited, 8(3), pp. 478-490.

Signori, G G, Guimarães, J C F De, Severo, E A and Rotta, C (2018) 'Gamification as an innovative method in the processes of learning in higher education institutions', International Journal of Innovation and Learning. Inderscience Publishers (IEL), 24(2), pp. 115-137.

Šimúth, J and Hvorecký, J (2016) 'E-Pedagogy as a Basis for E-Learning', International Conference on e-Learning. Bratislava, Slovakia.

Sumner, M and Powell, A (2013) 'What Project Management Competencies are Important to Job Success?', Nineteenth Americas Conference on Information Systems (AMCIS2013). Chicago, Illinois.

Svinicki, M D and Dixon, N M (1987) 'The Kolb model modified for classroom activities', College Teaching. Taylor \& Francis, 35(4), pp. 141-146. 
Walder, A M (2014) 'The concept of pedagogical innovation in higher education', Education Journal, 3(3), pp. 195-202.

Wenu, A and Tan, C (2019) 'The Applied, Knowledge, and Work-based oriented Project Management Coaching Framework (AKW-PMCF)', The Journal of Modern Project Management, 6(3).

Wilhelm, P and Beishuizen, J J (2003) 'Content effects in self-directed inductive learning', Learning and Instruction, 13(4), pp. 381-402.

Wilson, S M and Peterson, P L (2006) Theories of learning and teaching: What do they mean for educators? National Education Association Washington, DC.

Winter, M, Smith, C, Morris, P and Cicmil, S (2006) 'Directions for future research in project management: The main findings of a UK government-funded research network', International journal of project management. Elsevier, 24(8), pp. 638-649.

Wittrock, M C (1992) 'Generative learning processes of the brain', Educational Psychologist. Taylor \& Francis, 27(4), pp. 531-541.

WorkRFun (2020) Traffic Jam Team Building. Available at: https://workrfun.com/activities/63-Traffic-Jam-Team-Building/ (Accessed: 5 January 2020).

$\mathrm{Xu}$, Y and Wang, R (2014) 'Peer Reviewer Recommendation in Online Social Learning Context: Integrating Information of Learners and Submissions', Pacific Asia Conference on Information Systems (PACIS 2014) . Chengdu, China, p. 295.

Yoder, J D and Hochevar, C M (2005) 'Encouraging active learning can improve students' performance on examinations', Teaching of psychology. Taylor \& Francis, 32(2), pp. 91-95. 
Yu, A Y, Tian, S W, Vogel, D R and Kwok, R C-W (2010) 'Embedded Social Learning in

Online Social Networking', International Conference on Information Systems (ICIS2010). Saint Louis, Missouri, USA, p. 100.

Zadok, Y and Voloch, N (2018) 'Applying PBL to teaching robotics', International Journal of Innovation and Learning. Inderscience Publishers (IEL), 24(2), pp. 138-151.

Zetter, R (2002) 'Implementing teaching and research links in departments', Exchange, 3, pp. $12-14$.

Alam, M, Gale, A, Brown, M and Khan, A I (2010) 'The importance of human skills in project management professional development', International Journal of Managing Projects in Business, 3(3), pp. 495-516.

Anthopoulos, L G and Xristianopoulou, A (2012) Negotiation Models for Managing Projects. Master of Project Management thesis). Available at: http://mibes.teilar.gr/proceedings/2012/oral/Anthopoulos-Christianopoulou.pdf.

Assiter, A (1995) 'Transferable skills: A response to the sceptics', Transferable Skills in Higher Education. London, Kogan Page.

Axelos (2017) What is PRINCE2? | PRINCE2 | AXELOS, Axelos [Online]. Available at: https://www.axelos.com/best-practice-solutions/prince2/what-is-prince2 (Accessed: 1 February 2018).

Bandura, A and Walters, R H (1977) 'Social learning theory'.

Belbin, R M (2012) Team roles at work. Routledge. 
Bergman, I and Gunnarson, S (2014) 'Teaching organizational project management at postgraduate level', Procedia-Social and Behavioral Sciences. Elsevier, 119, pp. 446-455.

Bonwell, C and Eison, J (1991) Active Learning: Creating Excitement in the Classroom. 1991 ASHE-ERIC Higher Education Reports., ASHE-ERIC Higher Education Report.

Braun, V and Clarke, V (2006) 'Using thematic analysis in psychology', Qualitative research in psychology. Taylor \& Francis, 3(2), pp. 77-101.

Brennan, J and McGeevor, P (1987) Employment of Graduates from Ethnic Minorities: A Research Report. Commission for Racial Equality London.

Brew, A (2007) 'Integrating research and teaching: understanding excellence', in Skelton *, A. (ed.) International Perspectives on Teaching Excellence in Higher Education. Routledge.

Carless, D and Boud, D (2018) 'The development of student feedback literacy: enabling uptake of feedback', Assessment \& Evaluation in Higher Education. Routledge, 43(8), pp. 1315-1325.

Chiu, M M (2000) 'Group Problem-Solving Processes: Social Interactions andIndividual Actions', Journal for the theory of social behaviour, 30(1), pp. 26-49.

Chiu, M M (2008) 'Flowing toward correct contributions during group problem solving: A statistical discourse analysis', The Journal of the Learning Sciences, 17(3), pp. 415-463.

Córdoba, J-R and Piki, A (2012) 'Facilitating project management education through groups as systems', International Journal of Project Management. Elsevier, 30(1), pp. 83-93.

Dreyfus, S E (2004) 'The Five-Stage Model of Adult Skill Acquisition', Bulletin of Science, Technology \& Society, 24(3), pp. 177-181. 
Elliott, R and Timulak, L (2005) 'Descriptive and interpretive approaches to qualitative research', A handbook of research methods for clinical and health psychology, pp. 147-159.

Ewin, N, Luck, J, Chugh, R and Jarvis, J (2017) 'Rethinking Project Management Education: A Humanistic Approach based on Design Thinking', in Procedia Computer Science, pp. 503510.

Finkelstein, A, Ferris, J, Weston, C and Winer, L (2016) 'Research-Informed Principles for (Re)Designing Teaching and Learning Spaces', Journal of Learning Spaces.

Fisher, R, Ury, W and Patton, B (2011) Getting to Yes Negotiating an Agreement without Giving In. USA: Penguin Random House Business Books.

French, J R (1953) 'Experiments in field settings', in Research Methods in the Behavioral Sciences. New York: Rinehart and Winston, pp. 98-135.

Gherardi, S, Nicolini, D and Odella, F (1998) 'Toward a social understanding of how people learn in organizations: The notion of situated curriculum', Management Learning, 29(3), pp. 273-297.

González-Marcos, A, Alba-Elías, F, Navaridas-Nalda, F and Ordieres-Meré, J (2016) ‘Student evaluation of a virtual experience for project management learning: An empirical study for learning improvement', Computers \& Education. Elsevier, 102, pp. 172-187.

Goodpasture, J (2010) Project management the agile way: Making it work in the enterprise. J. Ross Publishing.

Gordon, N (2014) Using Pedagogy and Learning Analytics to Manage Our Students. Available at: https://www.heacademy.ac.uk/system/files/resources/gen-108-o.pdf. 
Gresty, K A, Pan, W, Heffernan, T and Edwards-Jones, A (2013) 'Research-informed teaching from a risk perspective', Teaching in Higher Education, 18(5), pp. 570-585.

Griffiths, R (2004) 'Knowledge production and the research-teaching nexus: The case of the built environment disciplines', Studies in Higher education, 29(6), pp. 709-726.

Guidry, B N and Totaro, M W (2013) 'MIS students and the systems analysis and design course project: a proposed experiential approach', International journal of innovation and learning. Inderscience Publishers Ltd, 13(2), pp. 121-139.

Hanke, U (2012) 'Generative Teaching: Improvement of Generative Learning', Encyclopedia of the Sciences of Learning. Springer, pp. 1358-1360.

Healey, M (2005) 'Linking research and teaching to benefit student learning', Journal of Geography in Higher Education, 29(2), pp. 183-201.

Healey, M and Jenkins, A (2009) Developing undergraduate research and inquiry. York: Higher Education Academy.

Huet, I (2017) 'Research-based education as a model to change the teaching and learning environment in STEM disciplines', European Journal of Engineering Education. Taylor \& Francis, pp. 1-16.

Ives, B, Valacich, J S, Watson, R T, Zmud, R W, Alavi, M, Baskerville, R, Baroudi, J J, Beath, C, Clark, T and Clemons, E K (2002) 'What every business student needs to know about information systems', Communications of the Association for Information Systems, 9(1), p. 30.

De Jong, T and Van Joolingen, W R (1998) 'Scientific discovery learning with computer simulations of conceptual domains', Review of educational research, 68(2), pp. 179-201. 
Khodeir, L M (2018) 'Blended learning methods as an approach to teaching project management to architecture students', Alexandria engineering journal. Elsevier, 57(4), pp. 3899-3905.

Kim, H (2012) 'Understanding Online Knowledge Contribution in Social Learning Perspective', European Conference of Information Systems (ECIS2012). Barcelona, p. 226.

Knight, J K and Wood, W B (2005) 'Teaching more by lecturing less', Cell biology education. Am Soc Cell Biol, 4(4), pp. 298-310.

Kolb, D A (1984) Experiential learning: experience as the source of learning and development. Prentice-Hall.

Kvale, S (1995) 'The social construction of validity’, Qualitative inquiry, 1(1), pp. 19-40.

Kytle, J (1978) 'Book Reviews: Social Learning Theory by Albert Bandura. Contemporary Sociology', pp. 84-85.

Laal, Marjan and Laal, Mozhgan (2012) 'Collaborative learning: what is it?', Procedia-Social and Behavioral Sciences, 31, pp. 491-495.

Lalonde, P L, Bourgault, M and Findeli, A (2012) 'An empirical investigation of the project situation: PM practice as an inquiry process', International Journal of Project Management.

Mansour, H F (2015) 'Enhancing first year management students' engagement: An action research project to explore the use of the Essay Feedback Checklist (EFC)', The International Journal of Management Education. Elsevier, 13(3), pp. 218-226.

Martin, N (2017) Prisoner's Dilemma (aka Reds \& Blues), WorkshopBank. Available at: 
https://workshopbank.com/prisoners-dilemma (Accessed: 1 November 2018).

McNally, B, Chipperfield, J, Dorsett, P, Del Fabbro, L, Frommolt, V, Goetz, S, Lewohl, J, Molineux, M, Pearson, A and Reddan, G (2017) 'Flipped classroom experiences: student preferences and flip strategy in a higher education context', Higher Education. Springer, 73(2), pp. 281-298.

Mishler, E G (1990) 'Validation in inquiry-guided research: The role of exemplars in narrative studies', Harvard educational review, 60(4), pp. 415-443.

Mitnik, R, Recabarren, M, Nussbaum, M and Soto, A (2009) 'Collaborative robotic instruction: A graph teaching experience', Computers \& Education, 53(2), pp. 330-342.

Morgan, S, Pullon, S and McKinlay, E (2015) 'Observation of interprofessional collaborative practice in primary care teams: an integrative literature review', International Journal of Nursing Studies. Elsevier, 52(7), pp. 1217-1230.

Newman, J H (2010) Discourses on the Scope and Nature of University Education: Addressed to the Catholics of Dublin. Cambridge University Press (Cambridge Library Collection Education).

Norton, L S (2009) Action research in teaching and learning: A practical guide to conducting pedagogical research in universities. Abingdon, UK: Routledge.

Osmani, M, Hindi, N M and Weerakkody, V (2018) 'Developing Employability Skills in Information System Graduates', International Journal of Information and Communication Technology Education, 14(2), pp. 17-29.

Paradis, E and Sutkin, G (2017) 'Beyond a good story: from Hawthorne Effect to reactivity in 
health professions education research', Medical education. Wiley Online Library, 51(1), pp. $31-39$.

Paulk, M C (2002) 'Agile Methodologies and Process Discipline', Institute for Software Research, pp. 15-18.

Pedaste, M, Mäeots, M, Siiman, L A, De Jong, T, Van Riesen, S A N, Kamp, E T, Manoli, C C, Zacharia, Z C and Tsourlidaki, E (2015) 'Phases of inquiry-based learning: Definitions and the inquiry cycle', Educational research review, 14, pp. 47-61.

Pedaste, M and Sarapuu, T (2006) 'Developing an effective support system for inquiry learning in a Web-based environment', Journal of Computer Assisted Learning, 22(1), pp. 47-62.

Pinto, J K, Slevin, D P and English, B (2009) 'Trust in projects: An empirical assessment of owner/contractor relationships', International Journal of Project Management.

Poole, V A and Zahn, D K (1993) 'Define and Teach Employability Skills to Guarantee Student Success', The Clearing House: A Journal of Educational Strategies, Issues and Ideas. Taylor \& Francis Group , 67(1), pp. 55-59.

Pratton, J and Hales, L W (1986) 'The effects of active participation on student learning', The Journal of Educational Research. Taylor \& Francis, 79(4), pp. 210-215.

Prince, M (2004) 'Does active learning work? A review of the research', Journal of engineering education. Wiley Online Library, 93(3), pp. 223-231.

ProjectManagementInstitute (2017) Job Growth and Talent Gap in Project Management 2017, 2017. Available at: https://www.pmi.org/-/media/pmi/documents/public/pdf/learning/jobgrowth-report.pdf?sc_lang_temp=en. (Accessed: 12 August 2019). 
Ramazani, J and Jergeas, G (2015) 'Project managers and the journey from good to great: The benefits of investment in project management training and education', International Journal of Project Management.

Ravindranath, S (2016) 'Soft Skills in Project Management: A Review', IUP Journal of Soft Skills.

Robson, C and McCartan, K (2016) Real World Research, Edition. Blackwell Publishing. Malden.

Sandelowski, M (1998) 'The call to experts in qualitative research', Research in nursing \& health, 21(5), pp. 467-471.

Saunders, M N K, Lewis, P and Thornhill, A (2016) Research Methods For Business Students (Seventh Edition). 7th editio. England: Pearson Education Limited.

Sense, A J (2011) 'The project workplace for organizational learning development', International Journal of Project Management.

Shelley, A W (2015) 'Project management and leadership education facilitated as projects', International Journal of Managing Projects in Business. Emerald Group Publishing Limited, 8(3), pp. 478-490.

Signori, G G, Guimarães, J C F De, Severo, E A and Rotta, C (2018) 'Gamification as an innovative method in the processes of learning in higher education institutions', International Journal of Innovation and Learning. Inderscience Publishers (IEL), 24(2), pp. 115-137.

Šimúth, J and Hvorecký, J (2016) 'E-Pedagogy as a Basis for E-Learning', International Conference on e-Learning. Bratislava, Slovakia. 
Sumner, M and Powell, A (2013) 'What Project Management Competencies are Important to Job Success?', Nineteenth Americas Conference on Information Systems (AMCIS2013). Chicago, Illinois.

Svinicki, M D and Dixon, N M (1987) 'The Kolb model modified for classroom activities', College Teaching. Taylor \& Francis, 35(4), pp. 141-146.

Walder, A M (2014) 'The concept of pedagogical innovation in higher education', Education Journal, 3(3), pp. 195-202.

Wenu, A and Tan, C (2019) 'The Applied, Knowledge, and Work-based oriented Project Management Coaching Framework (AKW-PMCF)', The Journal of Modern Project Management, 6(3).

Wilhelm, P and Beishuizen, J J (2003) 'Content effects in self-directed inductive learning', Learning and Instruction, 13(4), pp. 381-402.

Wilson, S M and Peterson, P L (2006) Theories of learning and teaching: What do they mean for educators? National Education Association Washington, DC.

Winter, M, Smith, C, Morris, P and Cicmil, S (2006) 'Directions for future research in project management: The main findings of a UK government-funded research network', International journal of project management. Elsevier, 24(8), pp. 638-649.

Wittrock, M C (1992) 'Generative learning processes of the brain', Educational Psychologist. Taylor \& Francis, 27(4), pp. 531-541.

WorkRFun (2020) Traffic Jam Team Building. Available at: https://workrfun.com/activities/63-Traffic-Jam-Team-Building/ (Accessed: 5 January 2020). 
$\mathrm{Xu}, \mathrm{Y}$ and Wang, R (2014) 'Peer Reviewer Recommendation in Online Social Learning Context: Integrating Information of Learners and Submissions', Pacific Asia Conference on Information Systems (PACIS 2014) . Chengdu, China, p. 295.

Yoder, J D and Hochevar, C M (2005) 'Encouraging active learning can improve students' performance on examinations', Teaching of psychology. Taylor \& Francis, 32(2), pp. 91-95.

Yu, A Y, Tian, S W, Vogel, D R and Kwok, R C-W (2010) 'Embedded Social Learning in Online Social Networking', International Conference on Information Systems (ICIS2010). Saint Louis, Missouri, USA, p. 100.

Zadok, Y and Voloch, N (2018) 'Applying PBL to teaching robotics', International Journal of Innovation and Learning. Inderscience Publishers (IEL), 24(2), pp. 138-151.

Zetter, R (2002) 'Implementing teaching and research links in departments', Exchange, 3, pp. $12-14$. 


\section{Appendix 1: Informal Feedback}

Open-ended questions for 2018 cohort

- What have you learned?

- How did you find this activity?

Open ended questions for 2019 cohort

- What have you learned?

- What have you learned from each other?

- What would you do differently when managing a conflict?

- What have you liked most in doing this activity?

- What have you liked less in doing this activity? 


\section{Appendix 2: Evaluation Survey (2018 cohort)}

By referring to the "Red vs Blue" activity that was conducted prior to the lecture on Conflict Management, please kindly tell us what you think about the activity.

\section{General Theme}

1. How many years have you worked in the professional environment?

○ None

○ 1-3 years

○ More than 3 years

If you have one or more than one year of professional work experience, please tell us more about your profession.

\section{Novelty Theme}

2. Do you think this activity is different compared to the usual teaching delivery?
○ Yes
○ No
○ Not sure
Others (please specify)

3. Did this activity surprise you?
○ Yes
○ No
○ Not sure
$\circ \quad$ Others (please specify) 


\section{Change Theme}

4. At what level has this activity changed the module delivery?

○ Light

○ Radical

No change

- Not sure (please specify)

\section{Reflection Theme}

5. Do you think this activity has helped you in researching the best way to resolve conflicts?

○ Yes

○ No

○ Not sure

O Others (please specify)

6. Do you think this activity has helped you learn better about Conflict Management and Negotiation theories?

○ Yes

○ No

○ Not sure

Others (please specify)

7. Do you think this activity has helped you to reflect on what you have learned in previous sessions in the Team Dynamic and Leadership module? 

○ Yes
○ No
○ Not sure
$\circ$ Others (please specify)

8. Do you think this activity has demonstrated to you how to apply what you have learned in the Team Dynamic and Leadership module in your future workplace?
○ Yes
○ No
○ Not sure
$\circ$ Others (please specify)

9. Did you find this activity engaging?
○ Yes
○ No
- Not sure
Others (please specify)

10. Any other comments for the "Team Dynamics and Leadership" module delivery in terms of the Content, Assessments and Activities? 


\section{Appendix 3: Evaluation Survey (2019 cohort)}

By referring to the "Red vs Blue" activity that was conducted prior to the lecture of Conflict Management, please kindly tell us what you think about the activity.

\section{General Theme}

1. How many years have you worked in a professional environment?

○ None

○ 1-3 years

○ More than 3 years

If you have one or more than one year of professional work experience, please tell us more about your profession. 


\section{Novelty Theme}

2. Do you think this activity is different when compared to the usual teaching delivery?

$\circ \quad$ Yes, please tell us why

○ No

○ Not sure

3. Did this activity surprise you?

○ Yes, please tell us why. What were you most surprised with?

○ No

- Not sure 


\section{Change Theme}

4. At what level has this activity changed the module delivery? Or has this activity changed the way you perceive the module delivery at the university?

○ Yes. If yes, to what extent has this delivery changed the way you perceive learning at the university?

○ No

○ Not sure

5. How have you changed your learning as a consequence of this activity?

- Light

○ Radical

No change

○ Not sure (please specify) 


\section{Reflection Theme}

6. Do you think this activity has helped you in researching the best way to resolve conflicts?
○ Yes
○ No
○ Not sure

6. Do you think this activity has helped you learn better about Conflict Management and Negotiation theories?
○ Yes
○ No
○ Not sure

7. Do you think this activity has helped you to reflect on what you have learned in previous sessions in the Team Dynamic and Leadership module?
○ Yes
○ No
○ Not sure

8. Do you think this activity has demonstrated to you how to apply what you have learned in the Team Dynamic and Leadership module in your future workplace?
○ Yes
$\circ$ No
○ Not sure 
9. Did you find this activity engaging?

○ Yes

○ No

○ Not sure

10. What have you liked most in doing this activity?

11. What have you liked less in doing this activity? 
12. Any other comments for the "Team Dynamics and Leadership" module delivery in terms of the Content, Assessments and Activities? 


\section{Figures}

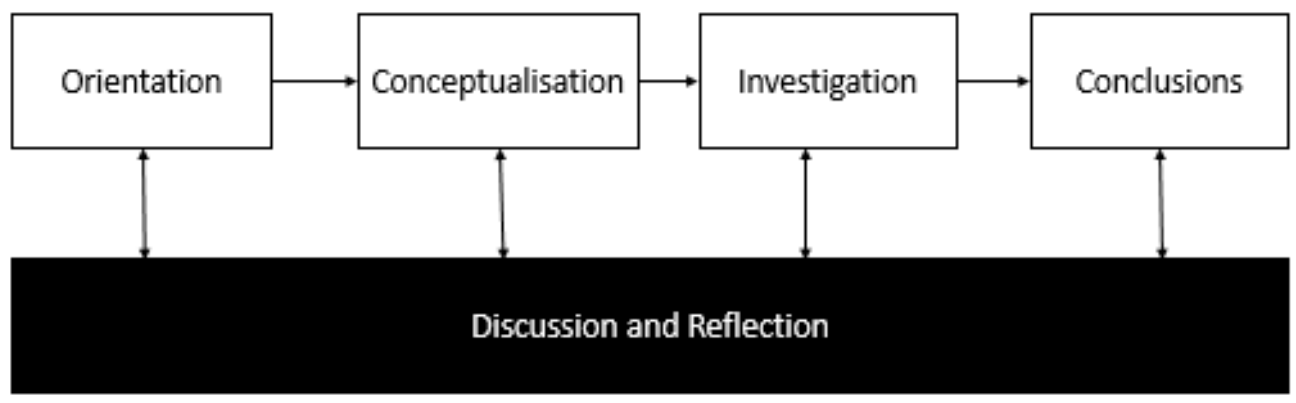

Figure 1 Learning Process in Research-informed Teaching where Students are seen as Participants (Pedaste et al., 2015)

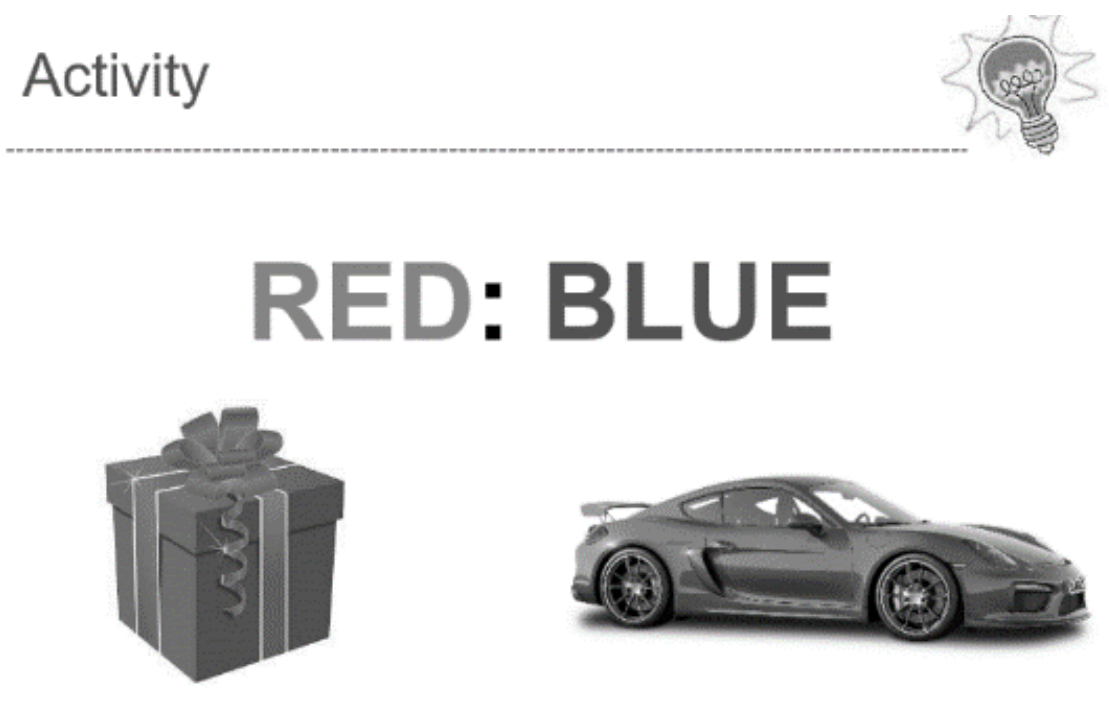

Figure 2 Red vs Blue Activity

\section{Instructions}

1. There are two teams $-\mathrm{A}$ and $\mathrm{B}-$ who will play 10 rounds of competition

2. You will choose to play either Red or Blue

3. You will be scored as per the $\underline{\text { Score Table }}$

4. The first 8 rounds are a maximum of 3 minutes each

5. You can have a conference, via representatives, with your opposing group after the fourth round (however, this can only take place at the request of both groups)

Figure 3 Activity Guidelines 
icore Table

\begin{tabular}{l|l|l|l}
\hline Group A & Group B & Score A & Score B \\
\hline Red & Red & +3 & +3 \\
\hline Red & Blue & -6 & +6 \\
\hline Blue & Red & +6 & -6 \\
\hline Blue & Blue & -3 & -3
\end{tabular}

Figure 4 Score Table

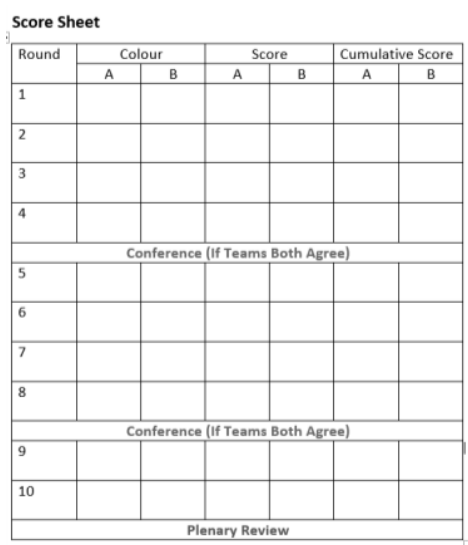

Figure 5 Score Sheet

\begin{tabular}{|l|c|l|c|c|c|c|c|}
\hline Round & \multicolumn{2}{|c|}{ Colour Played } & \multicolumn{2}{c|}{ Score } & \multicolumn{2}{c|}{ Cumulative Score } \\
& A & A & B & A & B \\
\hline 1 & Blue & Red & +6 & -6 & +6 & -6 \\
\hline 2 & Blue & Red & +6 & -6 & +12 & -12 \\
\hline 3 & Blue & Blue & -3 & -3 & 9 & -15 \\
\hline 4 & Blue & Red & +6 & -6 & +15 & -21 \\
\hline \multicolumn{7}{|c|}{ CONFERENCE (IF TEAMS BOTH AGREg } \\
\hline 5 & Red & Blue & -6 & +6 & +9 & +15 \\
\hline 6 & Red & Blue & -6 & +6 & 3 & -9 \\
\hline 7 & Blue & Blue & -3 & -3 & 0 & -12 \\
\hline 8 & Blue & Red & +6 & -6 & +6 & -18 \\
\hline \multicolumn{7}{|c|}{ CONFERENCE (IF TEAMS BOTH AGREF } \\
\hline 9 & Blue & Red & +12 & -12 & +18 & -30 \\
\hline 10 & Blue & Blue & -6 & -6 & +12 & -36 \\
\hline \multicolumn{7}{|c|}{ PLENARY REVIEW } \\
\hline
\end{tabular}

Figure 6 Activity results (2018 cohort) 


\begin{tabular}{|l|c|l|c|c|c|c|c|}
\hline Round & \multicolumn{2}{|c|}{ Colour Played } & \multicolumn{2}{c|}{ Score } & \multicolumn{2}{c|}{ Cumulative Score } \\
& A & B & A & B & A & B \\
\hline 1 & Blue & Red & +6 & -6 & +6 & -6 \\
\hline 2 & Blue & Red & -3 & -3 & +3 & -9 \\
\hline 3 & Blue & Blue & -3 & -3 & 0 & -12 \\
\hline 4 & Blue & Red & +3 & +3 & +3 & -9 \\
\hline \multicolumn{7}{|c|}{ CONFERENCE (IF TEAMS BOTH AGREE) } \\
\hline 5 & Red & Blue & -6 & +6 & -3 & -3 \\
\hline 6 & Red & Blue & +3 & +3 & 0 & 0 \\
\hline 7 & Blue & Blue & -6 & +6 & -6 & 6 \\
\hline 8 & Blue & Red & +6 & -6 & 0 & 0 \\
\hline 9 & CONFERENCE (IF TEAMS BOTH AGREE) \\
\hline 9 & Blue & Red & +12 & -12 & +12 & -12 \\
\hline 10 & Blue & Blue & +12 & -12 & +24 & -24 \\
\hline \multicolumn{7}{|c|}{ PLENARY REVIEW } \\
\hline
\end{tabular}

Figure 7 Activity results (2019 cohort)

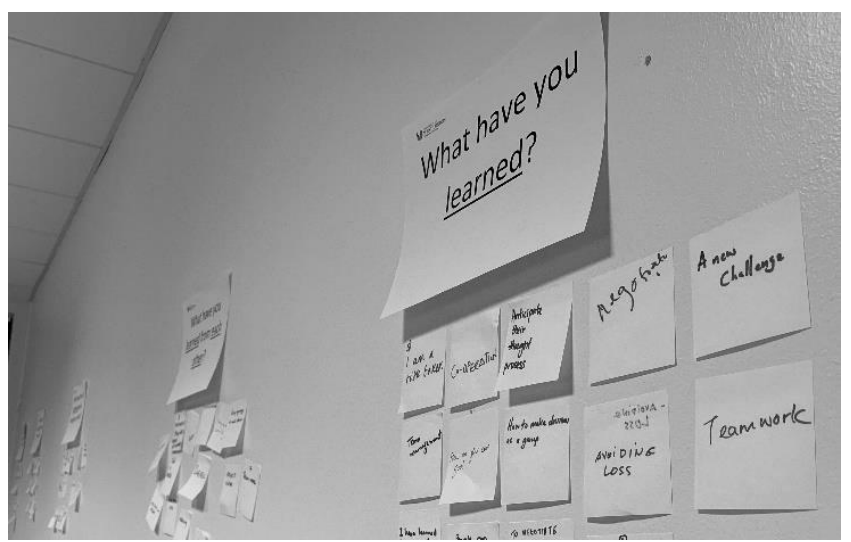

Figure 8 Post-it notes from the informal feedback session with the 2019 cohort

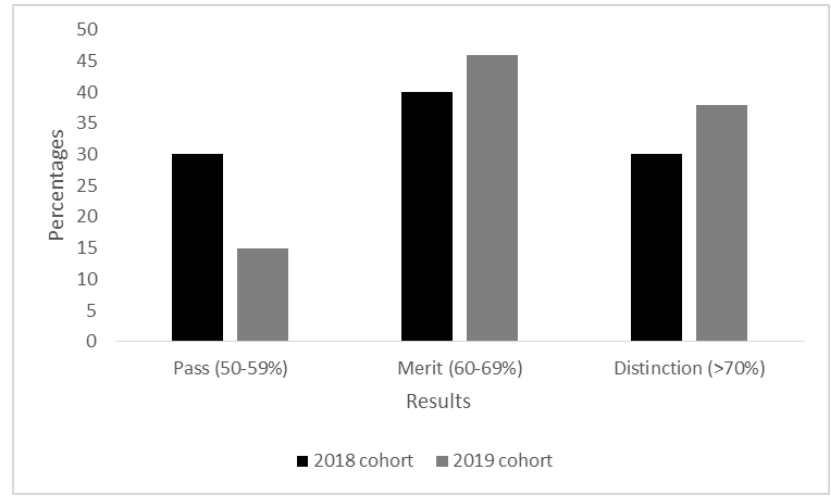

Figure 9 Module Assessment Results 


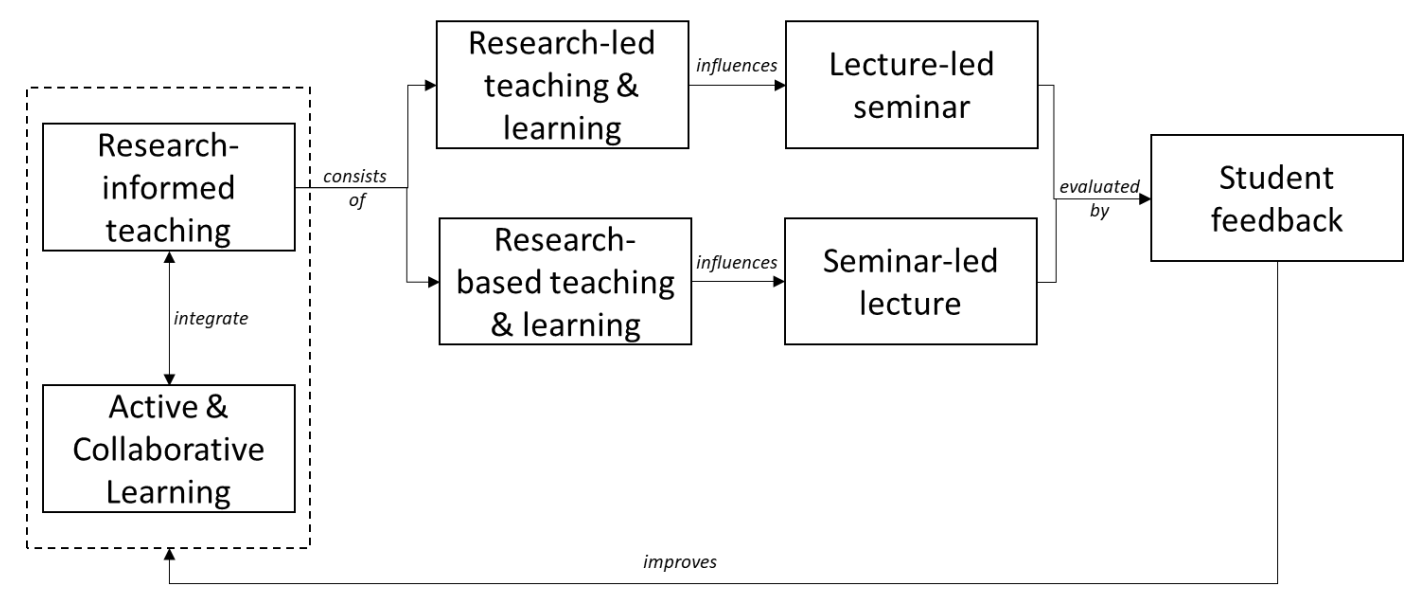

Figure 10 Teaching and Learning Delivery of Project Management Education 


\section{Tables}

Table 1 Number of participants and description of work experience

\begin{tabular}{|c|c|c|c|c|c|}
\hline Cohort & \multicolumn{2}{|c|}{ Year of professional work experience } & $\begin{array}{c}\text { Sectors of professional work } \\
\text { experience }\end{array}$ & $\begin{array}{c}\text { Total } \\
\text { students }\end{array}$ \\
\cline { 2 - 4 } & 0 & $1-3$ years & $\begin{array}{c}\text { More than } 3 \\
\text { years }\end{array}$ & & 20 \\
\hline 2018 & 3 & 6 & 11 & $\begin{array}{c}\text { IT, healthcare, construction } \\
\text { management, customer } \\
\text { services, } \\
\text { telecommunication, and } \\
\text { self-employed }\end{array}$ & 13 \\
\hline 2019 & 1 & 7 & 5 & $\begin{array}{c}\text { IT, social care, security } \\
\text { management, retail, } \\
\text { aviation, property } \\
\text { management, and self- } \\
\text { employed }\end{array}$ & \\
\hline
\end{tabular}


Table 2 Non-participant observation results

\begin{tabular}{|c|c|c|}
\hline \multirow[t]{2}{*}{ Learning Process } & \multicolumn{2}{|c|}{ Observations / Descriptions } \\
\hline & 2018 & 2019 \\
\hline Orientation & $\begin{array}{l}\text { Students were driven into the } \\
\text { problem domain, and they were } \\
\text { required to discover the potential } \\
\text { issues. On average, both teams } \\
\text { took } 2-3 \text { rounds to identify the } \\
\text { team objectives for this activity. }\end{array}$ & $\begin{array}{l}\text { Similarly, both teams were trying } \\
\text { to figure out the issues to be } \\
\text { resolved and the objectives. Both } \\
\text { teams took } 2-3 \text { rounds to devise the } \\
\text { team objectives for this activity. }\end{array}$ \\
\hline Conceptualisation & $\begin{array}{l}\text { Both teams made an empirical } \\
\text { hypothesis that this activity was } \\
\text { about winning before the first } \\
\text { conference (after round } 4 \text { ). } \\
\text { However, the losing teams were } \\
\text { quick to identify the strategy for } \\
\text { them to regain their winning } \\
\text { position. }\end{array}$ & $\begin{array}{l}\text { In the first three rounds, the } \\
\text { winning team tried to work out the } \\
\text { "winning" strategy by guessing } \\
\text { what the other team would play. } \\
\text { However, the losing team paused } \\
\text { and tried to reflect on the } \\
\text { negotiation theories (e.g., BATNA } \\
\text { - Best Alternative to a Negotiated } \\
\text { Agreement) they had learned } \\
\text { during the last week, and they } \\
\text { leaned towards the idea of } \\
\text { proposing a win-win strategy to the } \\
\text { winning team. }\end{array}$ \\
\hline Investigation & $\begin{array}{l}\text { Both teams performed the data } \\
\text { collection in both conferences } \\
\text { (after round } 4 \text { and round 8). In } \\
\text { the first conference, the losing } \\
\text { teams tried to negotiate a deal } \\
\text { with the winning teams (e.g., } \\
\text { asking the winning team to play } \\
\text { Red and they would play Blue so } \\
\text { that they could catch up with the } \\
\text { score). } \\
\text { There was a deal in round } 4 \text {. } \\
\text { However, the winning team did } \\
\text { not keep their promise. Hence, } \\
\text { the losing side was still losing. } \\
\text { The situation caused a massive } \\
\text { conflict in round } 8 \text { where the } \\
\text { losing team raised the trust issue. } \\
\text { Things changed when it came to } \\
\text { round } 8 \text { where both teams finally } \\
\text { applied BATNA theory, which } \\
\text { they had learned in the previous }\end{array}$ & $\begin{array}{l}\text { Similarly, both teams performed } \\
\text { the data collection in the first } \\
\text { conference (after round 4). The } \\
\text { winning team proposed a strategy } \\
\text { to help the losing team to regain } \\
\text { some points. However, they } \\
\text { wanted to keep the winning } \\
\text { position. The representatives from } \\
\text { both teams sent for the first } \\
\text { conference were good friends. } \\
\text { Hence, the representative from the } \\
\text { losing team proposed a win-win } \\
\text { strategy and emphasised the trust } \\
\text { element. } \\
\text { However, the representatives did } \\
\text { not manage to agree on a deal due } \\
\text { to time restrictions. The } \\
\text { representatives missed out an } \\
\text { important instruction, whereby } \\
\text { they had only } 3 \text { minutes for each } \\
\text { round including the conference. As }\end{array}$ \\
\hline
\end{tabular}




\begin{tabular}{|c|c|c|}
\hline & $\begin{array}{l}\text { lecture. Eventually, the winning } \\
\text { team kept their promises in } \\
\text { round } 10 \text { and this increased the } \\
\text { scores of the losing team. } \\
\text { Both teams had to face internal } \\
\text { conflicts where team members } \\
\text { did not agree with each other } \\
\text { about the approach to the game } \\
\text { (whether they would keep } \\
\text { winning or help the other team to } \\
\text { win). Both teams also dealt with } \\
\text { external conflicts when it came } \\
\text { to the negotiation conference } \\
\text { (round } 4 \text { and } 8 \text { ). }\end{array}$ & $\begin{array}{l}\text { a result, both teams again tried to } \\
\text { figure out the game plan for the } \\
\text { way forward. Eventually, both } \\
\text { teams played their cards randomly, } \\
\text { which caused the two teams to be } \\
\text { in a tied position in round } 8 \text {. } \\
\text { There were no internal or extreme } \\
\text { external conflicts. } \\
\text { The winning team requested the } \\
\text { second conference. However, the } \\
\text { losing team lost interest at that } \\
\text { point and refused the conference. } \\
\text { Eventually, the winning team } \\
\text { ended up with }+24 \text {, whereas the } \\
\text { losing team finished with }-24 \text {. }\end{array}$ \\
\hline Conclusions & $\begin{array}{l}\text { Both teams concluded during the } \\
\text { process that negotiation skills } \\
\text { were employed to manage the } \\
\text { conflict externally with the other } \\
\text { team and internally with their } \\
\text { team members. }\end{array}$ & $\begin{array}{l}\text { Both teams acknowledged the } \\
\text { importance of negotiation skills in } \\
\text { managing conflicts or } \\
\text { disagreements. The losing team } \\
\text { took the activity light-heartedly as } \\
\text { they perceived that the activity was } \\
\text { "just a game." }\end{array}$ \\
\hline $\begin{array}{l}\text { Discussion and } \\
\text { Reflection }\end{array}$ & $\begin{array}{l}\text { The teacher summoned the } \\
\text { students back to the lecture } \\
\text { room, and the teacher went } \\
\text { through the details of the } \\
\text { activity. }\end{array}$ & $\begin{array}{l}\text { The teacher summoned the } \\
\text { students back to the lecture room, } \\
\text { and the teacher went through the } \\
\text { details of the activity. This time, } \\
\text { the teacher provided a real-life } \\
\text { project management scenario (a } \\
\text { significant programme with } \\
\text { multiple project teams, such as the } \\
\text { Olympics 2012) to drive the } \\
\text { discussion. }\end{array}$ \\
\hline
\end{tabular}


Table 3 Informal feedback from the students

\begin{tabular}{|c|c|c|}
\hline Themes & 2018 & 2019 \\
\hline Engagement & $\begin{array}{l}\text { - The students felt the } \\
\text { intervention was } \\
\text { engaging. }\end{array}$ & $\begin{array}{l}\text { - The students felt the intervention was } \\
\text { engaging }(n=11) \\
\text { - However, they did not like the } \\
\text { uncertainty that they had to deal with in } \\
\text { the activity }(n=2)\end{array}$ \\
\hline $\begin{array}{l}\text { Learning } \\
\text { gains }\end{array}$ & $\begin{array}{l}\text { - The students thought that } \\
\text { they might not be able to } \\
\text { learn as much if the } \\
\text { intervention did not } \\
\text { happen. } \\
\text { - The intervention enabled } \\
\text { them to research a better } \\
\text { way of resolving } \\
\text { conflicts. }\end{array}$ & $\begin{array}{l}\text { The students found that apart from } \\
\text { negotiation and conflict management, } \\
\text { they also learned the following vital } \\
\text { skills in project management: } \\
\circ \text { Risk-taking/willing to take a } \\
\text { new challenge }(\mathrm{n}=3) \\
\circ \text { Cooperation/teamwork }(\mathrm{n}=13) \\
\circ \text { Critical thinking (learn to think, } \\
\text { and others thought process) } \\
(\mathrm{n}=7) \\
\circ \text { Goal focus }(\mathrm{n}=2) \\
\circ \text { Decision making }(\mathrm{n}=2) \\
\circ \text { Active listening }(\mathrm{n}=3) \\
\circ \text { Strategic planning }(\mathrm{n}=7)\end{array}$ \\
\hline $\begin{array}{l}\text { Collaborative } \\
\text { learning }\end{array}$ & - N/A & $\begin{array}{l}\text { - The students felt that they had learned } \\
\text { the following principles in managing a } \\
\text { successful project team by collaborating } \\
\text { and working with their peers in this } \\
\text { intervention: } \\
\circ \text { Team respect and trust } \\
\text { determine team success }(\mathrm{n}=12) \\
\circ \text { Tenacity working in extreme } \\
\text { situation }(\mathrm{n}=13)\end{array}$ \\
\hline Satisfaction & $\begin{array}{l}\text { - The overall satisfaction } \\
\text { was positive. }\end{array}$ & $\begin{array}{l}\text { - The overall satisfaction was positive } \\
(\mathrm{n}=13) \\
\text { - The students particularly liked the } \\
\text { following aspects of the intervention: } \\
\text { O Collaboration }(\mathrm{n}=5) \\
\circ \text { Active listening }(\mathrm{n}=3) \\
\text { O Strategic planning (making } \\
\text { strategic moves into real-life } \\
\text { situations) (n=5) } \\
\text { - The students also reflected that the } \\
\text { "uncertainty" was the aspect they liked } \\
\text { least }(\mathrm{n}=2)\end{array}$ \\
\hline
\end{tabular}


Table 4 Evaluation survey results

\begin{tabular}{|c|c|}
\hline \multicolumn{2}{|c|}{ Novelty } \\
\hline 2018 & $\begin{array}{l}75 \% \text { of the students felt that the intervention was different compared to the usual } \\
\text { teaching delivery. A student who had more than three years' work experience } \\
\text { expressed that "The activity was interesting and captivating in the sense that I } \\
\text { remember that day where Negotiation was not considered as a win-win game for } \\
\text { my team but a game of power where the most powerful win. I have learned that } \\
\text { negotiation is not all about winning but compromising and thinking in the } \\
\text { business interest, not personal gain only. Win without giving in is possible if the } \\
\text { right skills are used." } \\
85 \% \text { of the students commented that this intervention had surprised them. The } \\
\text { same student added "Yes I was not expecting the outcome that we were aiming to } \\
\text { achieve to be so wrong as when translated in the real business world. We were } \\
\text { thinking in a completely opposite direction of the negotiation. It was really } \\
\text { practical, current and fit for the purpose." }\end{array}$ \\
\hline 2019 & $\begin{array}{l}92 \% \text { of the students felt that the intervention was different compared to the usual } \\
\text { teaching delivery. A student who had 1-3 years' work experience thought "this } \\
\text { activity helps to think about previous classes. It helps us work in a team to } \\
\text { understand each other better." Most students with more than three years' work } \\
\text { experience felt that this activity forced them to think critically about a solution } \\
\text { rather than being entrenched in their position. } \\
62 \% \text { of the students commented that this intervention surprised them. Those who } \\
\text { felt surprised by the activity thought there would be a lecture before jumping } \\
\text { straight into the activity. Students who were not surprised by the activity thought } \\
\text { this was just a game and were not sure what was going on. }\end{array}$ \\
\hline \multicolumn{2}{|c|}{ Change } \\
\hline 2018 & $\begin{array}{l}47 \% \text { of the students felt that the intervention had brought a light change to the } \\
\text { module delivery, } 37 \% \text { indicated a radical change, } 5 \% \text { suggested no change, and } \\
\text { the rest were unsure. The students who picked unsure and no change purported } \\
\text { that "the activity was very interactive" and "it has enhanced my understanding } \\
\text { and developed more interest in moving forward a new method." }\end{array}$ \\
\hline 2019 & $\begin{array}{l}31 \% \text { of the students felt that the intervention had brought a light change, radical } \\
\text { change or no change to the module delivery. The rest were unsure. A student who } \\
\text { indicated light change claimed that "It's not a typical sit down for three whole } \\
\text { hours and listen to someone speak / teach." A student who had more than three } \\
\text { years' work experience picked radical change and confessed that "I have } \\
\text { depended on knowledge gained in the industry. I will have to radically change } \\
\text { this mindset and use theoretical and academic knowledge going forward", } \\
\text { whereas a student who picked no change suggested that this activity was } \\
\text { enjoyable and had contributed to their understanding of the theories and } \\
\text { framework. }\end{array}$ \\
\hline
\end{tabular}




\begin{tabular}{|c|c|}
\hline 2018 & $\begin{array}{l}100 \% \text { of the students claimed that this intervention had helped them in researching the } \\
\text { best way of resolving conflicts. In addition, all of the students felt that this intervention } \\
\text { had helped them to learn better about the conflict management and negotiation theories. } \\
\text { Two students who had more than three years' work experience commented that } \\
\text { "Excellent way of learning" and "Definitely to the extent where I end up buying a book } \\
\text { for a better understanding of how to negotiate in the business world." The results } \\
\text { suggest that somehow this intervention successfully engaged the working professional } \\
\text { students to search for and apply academic sources in dealing with real-life issues in the } \\
\text { project management environment. } \\
95 \% \text { of the students commented that the intervention had helped them to reflect the } \\
\text { previous theories they had learned in the module. They also believed that this } \\
\text { intervention would help them in applying the negotiation and conflict management } \\
\text { theories in their future workplace. A student who had more than three years' work } \\
\text { experience expressed that "Not only has this activity helped me with my negotiation skills } \\
\text { in business but in the work I try not to compromise too much and try to listen and see } \\
\text { how far the other is ready to give in." }\end{array}$ \\
\hline 2019 & $\begin{array}{l}46 \% \text { of the students felt that this intervention had helped in researching the best } \\
\text { way of resolving conflicts; } 31 \% \text { did not think this intervention was helpful. } \\
69 \% \text { felt that somehow the activity had helped them to reflect the previous } \\
\text { theories they had learned in the module, and } 92 \% \text { of the students believed that } \\
\text { this intervention would help them in negotiation and managing conflicts in their } \\
\text { future workplace. }\end{array}$ \\
\hline \multicolumn{2}{|r|}{ Overall Comments } \\
\hline 2018 & $\begin{array}{l}\text { The students who had more than three years' work experience found that this } \\
\text { module had covered the related theories they needed to know in the module, for } \\
\text { example, the theories about project structures, different team dynamics and team } \\
\text { composition, and to process the skills required to lead a team, such as negotiation } \\
\text { and conflict management. One of them commented that "this activity was chosen } \\
\text { in a very clever way and did reinforce my understanding. Happy with the content, } \\
\text { activities and assessments." As for those students who had one to three years' } \\
\text { work experience, one student felt that there should be an additional tutor helping } \\
\text { with the intervention to reduce the activity time and increase the communication } \\
\text { efficiency. As for those students who had no work experience, they indicated that } \\
\text { they would like to have more similar activities to enhance their learning and to } \\
\text { see how theories could apply in the real world. One student also suggested having } \\
\text { such an activity as part of their formal assessment. }\end{array}$ \\
\hline 2019 & $\begin{array}{l}\text { The student who did not have prior work experience felt that more information } \\
\text { should be provided. Most of the students who had 1-3 years' work experiences } \\
\text { indicated that the activity had helped them to understand how to manage conflicts } \\
\text { in real life situations and had also enabled them to understand the theories better. } \\
\text { Students who possessed more than three years' work experience felt that clear } \\
\text { guidance should be provided in terms of the learning outcomes so that they could } \\
\text { grasp the essence of the activity. }\end{array}$ \\
\hline
\end{tabular}

